\title{
Steers Afloat: The North Atlantic Meat Trade, Liner Predominance, and Freight Rates, 1870-1913
}

\section{KNICK HARLEY}

Meat transformed North Atlantic shipping, leading to dominance of liners and changed the economics of freight rates. Management coordination of meat shipment led to concentration in shipping. Only liner companies could provide specialized ships with the regularity needed and they dominated North Atlantic shipping. The cargo capacity of cattle ships, beyond that used for animals, lowered freight rates on grain below levels that would otherwise have prevailed. The berth rate on wheat from New York to Liverpool was most affected. Consequently, this readily available freight rate can be potentially misleading as an indicator of ocean shipping developments.

I $\mathrm{n}$ the late nineteenth century, Europe - particularly Britain - tapped the land abundance of the periphery for food. North America-United States and Canada - was the most important supplier and shipping played a central role. By the end of the century, most North Atlantic shipping had concentrated into the hands of large liner companies, even though tramp shipping remained dominant in other bulk shipping trades. Although aspects of liner companies have been extensively studied, the economics of their dominance of the North Atlantic still needs analysis.

America during the nineteenth century primarily exported bulk agricultural products and imported valuable manufactured goods; consequently bulk and weight of cargoes shipped from America to Europe vastly exceeded cargoes flowing westward. ${ }^{1}$ Antebellum cotton, and then growing exports of grain, ensured that vessels returning from

The Journal of Economic History, Vol. 68, No. 4 (December 2008). (C) The Economic History Association. All rights reserved. ISSN 0022-0507.

C. Knick Harley is Professor of Economic History, Department of Economics and St. Antony's College, University of Oxford, Manor Road Building, Oxford OX1 3UQ, United Kingdom. E-mail: knick.harley@economics.ox.ac.uk.

This article, in various forms, has been around for a long time and I have benefited from many comments in presentations including the International Maritime History Association meeting in Corfu in June 2004, the workshop on market performance and the welfare gains of market integration in history at the European University Institute in July 2004, the International Cliometrics Conference in Venice in July 2004, seminars at the University of Western Ontario, Trinity College Dublin, the London School of Economics, and the University of Groningen. I have also benefited from the careful and insightful comments of referees and the editor of this JOURNAL.

${ }^{1}$ By the end of the nineteenth century, the United States was importing significant amounts of raw materials, but this barely affected conditions on the North Atlantic. 
Europe had excess capacity and westbound freight rates were low. It is not generally appreciated, however, that conditions determining freight rates changed dramatically in the early 1880 s. A relatively small number of liner companies running extensive fleets-some concentrating on passengers and some on cattle and freight - came to dominate bulk shipment on the North Atlantic. At the same time, freight rates on American export - most notably the benchmark rate on grain from New York to Liverpool-fell sharply. Both changes appear to be largely a consequence of the rapid emergence of a transatlantic trade in meat - most notably, the shipment of steers for British slaughter rather than slaughtered meat.

Prior to the $1880 \mathrm{~s}$, a few large passenger liner companies and many small tramp shipping companies - often owning and operating a single vessel-carried North Atlantic cargoes. The domination of liner companies after 1880 was not driven by technological economies of scale (as concentration was in railroads - the other instrument of the nineteenth century transportation change). The technology of shipping bulk commodities provides few economies of scale to multiship companies. Cargo liner companies displaced tramp shipping because cattle transportation required closer coordination and regularity than other American exports. Large companies that could organize regular shipping dates gained a commercial advantage.

Cattle ships had shipping space in addition to that used by cattle and this resulted in liners dominating bulk cargoes as well. Cattle ship capacity reduced other American export freight rates. To be sure, mechanical technology was lowering freight rates worldwide, but North Atlantic grain freight fell much faster than other rates because of inherent jointness in production of different shipping services. The most obvious jointness occurs because a ship that sails from America to Europe must return to America in order to ship a second cargo- the greater bulk of eastbound cargoes resulted in excess westbound capacity and eastbound rates exceeding westbound rates - but other forms occur and the Atlantic meat trade provided a clear example. A ship transporting live animals to Britain had (eastbound) space for heavy cargoes. The magnitude of cattle shipment was such that capacity for heavy cargoes eastward became excess like westbound capacity. The result was a fall in eastbound bulk freights. Cattle ship operators' competition for bulk cargo to fill this excess capacity led to dramatic declines in freight rates on grain, which no longer paid the bulk of the costs of transatlantic round trips. Instead those costs now fell on cattle. 


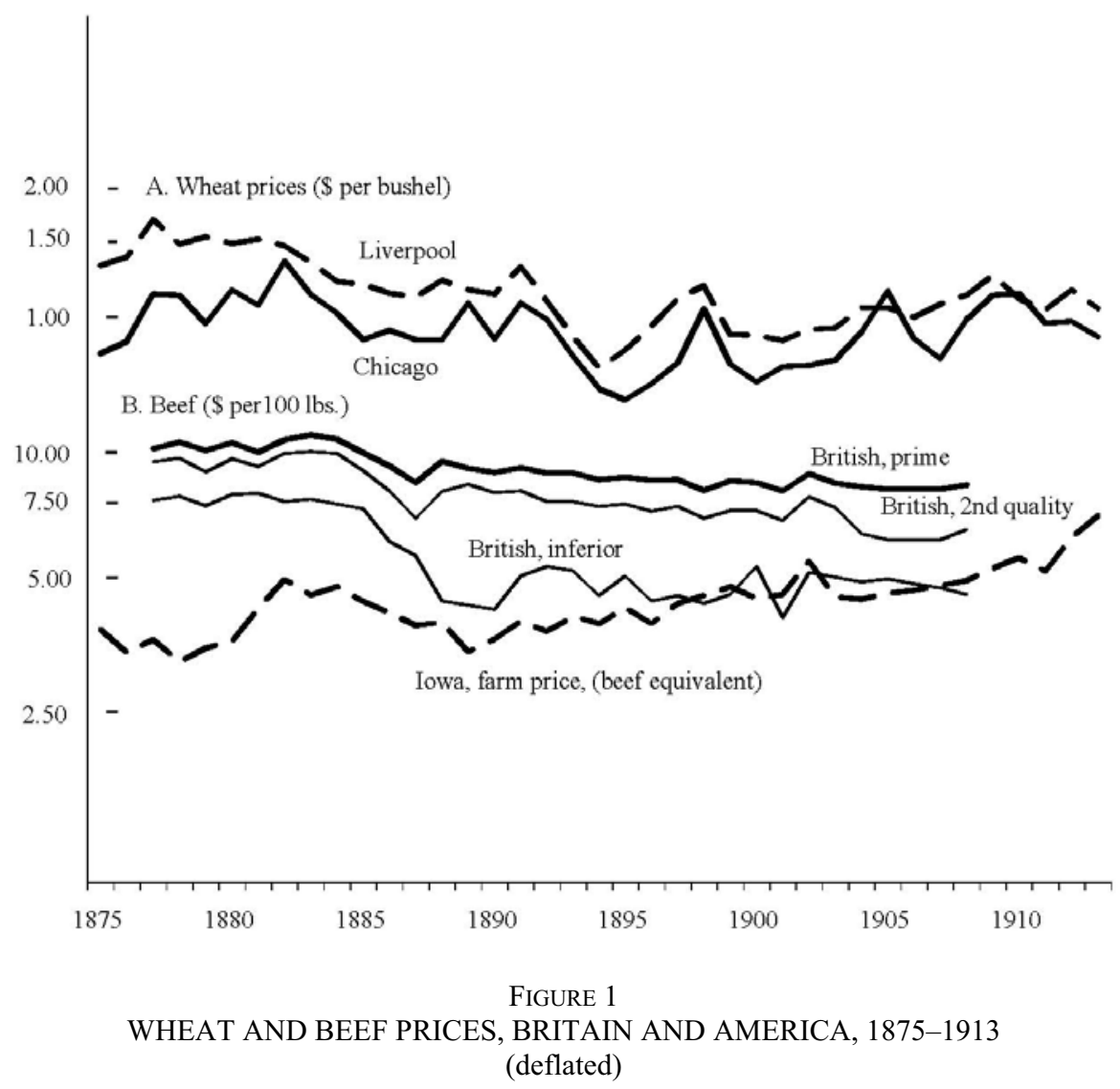

Note: Prices are deflated from the implicit deflator for U.K. national income $1913=100$ (Feinstein, National Income, T 132). They are expressed in dollars at prevailing exchange rates.

Sources: Wheat prices: Harley, "Transportation," pp. 246-47 (Liverpool, American Winter, Chicago, No. 2 Spring). Meat: Iowa: Strand, Prices (Iowa price has been divided by .55 to convert live weight to meat. British price is dead weight). Britain: Hooker, "Meat Supply," p. 365.

The nineteenth-century grain trade has been studied extensively, but the trade in meat and animals for slaughter, with its nearly comparable value and its striking organizational consequences, is relatively poorly explored. ${ }^{2}$ Globalization occurred as prices converged between Britain and America (Figure 1). Production adjusted in response-most notably, the frontier expanded into continental interiors - in a complex process that took time to effect and dominated developments in the global economy for some thirty years. In the grain trade, intercontinental specialization did not greatly change the organization of the industry. Production expanded into the interior of the United States, southern

\footnotetext{
${ }^{2}$ Malenbaum, World Wheat Economy; Jasny, Competition; Harley, "Western Settlement," "North Atlantic Shipping," and "World Food Economy"; and O'Rourke and Williamson, Globalization.
} 
Russia, and elsewhere largely on the basis of the existing, even if very different, agricultural techniques in each region. Certainly firms introduced innovations and improvements in organization-automatic handling of grain in bulk and futures markets - but, although clearly an oversimplification, one may say without too much injustice that change consisted mainly of lowering the cost of transportation in an already sophisticated trade. ${ }^{3}$ Long-distance trade in meat caused much more fundamental changes. Preserved meat, both bacon and ham and pickled beef, had long been traded, but only in the 1870s did high quality meat, in the form of live animals, chilled beef, and mutton, enter intercontinental trade. Lower transportation costs, faster shipment, and increased demand from increasing population and income drove developments as they did in grain. The impact of new technology, however, cannot be summarized, even superficially, as simply lower freight rates in an existing distribution network. Conditions of meat supply altered fundamentally, requiring institutional revolutions in wholesale and retail distribution. Regulation and technology combined to replace an age-old system by which live animals essentially walked from the farm to the retail butcher shops with a new system, where slaughter was centralized and meat moved through a wholesale trade to the retail butchers. Longdistance trade in meat began in America, where the great packing houses-Swift, Armour, Hammond, and Morris-emerged dominant. The same firms came to dominate the transatlantic trade. Ocean shipment of meat and cattle provided conditions that gave advantages to large liner companies that came to dominate North Atlantic shipping, even in bulk trades.

\section{THE LONG-DISTANCE MEAT TRADE: AMERICAN DEVELOPMENT AND CHARACTER}

The American meat trade developed soon after the American Civil War as New England and the mid-Atlantic cities came to depend on meat shipped east on the railroads. A little over a decade later, the trade expanded to Britain and by 1900, the value of Britain's meat imports exceeded the value of wheat imports by about a third. The broad outline of the meat trade was similar to the grain trade - although largescale international shipments were confined to Britain. British and eastern American prices fell and American producer prices rose as transportation costs fell and markets integrated (Figure 1).

\footnotetext{
${ }^{3}$ It would be misleading to slight the sophistication in the British grain trade that had developed in response to the complexities of the early nineteenth-century Corn Laws.
} 
The North American export trade in beef (and mutton) evolved quite differently from the trade in pig meat, so it is useful to follow the traditional distinction between pig meat and butchers' meat. ${ }^{4}$ Pig meat trade continued in traditional preserved forms-bacon and ham. In 1900 bacon, ham, and other salt pork made up $£ 16.2$ million of Britain's total pig meat imports of $£ 17.7$ million (92 percent). Thirteen million British pounds of this came from North America and most of the balance from Denmark. Shipment of salted pork and beef from the western United States had predated those of grain, and U.S. shipments of provisions to Britain began to grow rapidly only slightly later than American grain exports. Pig meat preserved by traditional methods continued to be shipped without major innovations. ${ }^{5}$ While there are some issues of the quality of the product (American pig meat tended to be fatty, for example), the history of the trade is essentially similar to that for grain. Increasing population stimulated demand and falling transportation costs encouraged international specialization.

Trade in beef developed in a more complicated manner. The change originated in America and has been well studied. ${ }^{6}$ Railroad shipment of beef after the Civil War began a transformation. In the 1870s and 1880s, meat slaughtered in centralized Chicago facilities was distributed refrigerated to the East. Chicago meat packers innovated to centralize cattle slaughter and to transport and market highly perishable fresh meat. Shipping meat saved in transport costs since-once the refrigerated railroad cars became efficient - meat was much cheaper to transport than live cattle. Shipment of meat obviated shipment of inedible parts of the carcass and removed the costs of meeting the special needs of live cattle in transit. Centralized slaughter also provided opportunities for packing houses to capture economies of scale, particularly in the use of by-products. Consequently, Chicago-processed meat became an important part of meat supply of urban America, although live animals continued to be shipped east. ${ }^{7}$ By the 1880s New England and the large eastern cities depended on western beef in a way that would have been impossible without railroads and refrigeration, and the industry had been transformed. Gustavus Franklin Swift's improved refrigerated rail cars enabled him to ship beef

\footnotetext{
${ }^{4}$ Mutton and sheep exports were a relatively small trade. At its peak in the late 1890 s, sheep exports provided meat equal to about 4 percent of the beef trade. See Hooker, "Meat Supply," p. 358.

5 "Provision Trade," Monthly Summary of Commerce and Finance, 2313-27.

6 "Provision Trade," Monthly Summary of Commerce and Finance; Aduddell and Cain, "Location and Collusion" and "Public Policy"; Chandler, Visible Hand; and Yeager, Competition, chapter 2 .

${ }^{7}$ Nimmo, Internal Commerce, pp. 58, 63; and "Provision Trade," Monthly Summary of Commerce and Finance, 2295.
} 
dressed in Chicago to eastern cities in the late 1870s, and rival packers, Armour, Morris, and Hammond, who were already experimenting with shipping meat by rail, emulated his success almost immediately. Each firm developed a fleet of refrigerated rail cars and an eastern distribution network. By the mid-1880s, the big packers had grown, at the expense of rivals, to the extent that they slaughtered some 85 percent of the cattle butchered in Chicago. ${ }^{8}$

Specific capital and organizational coordination centralized the industry in the hands of a few integrated firms. Marketing refrigerated beef successfully involved new distribution systems that required innovations and investments in physical and human capital that were particular to the industry. As Oliver Williamson has pointed out, situations with transaction-specific assets are difficult to maintain with spot market between various stages of production and distribution. ${ }^{9}$ As a result, hierarchical organizations have advantages that allow them to dominate. Fresh meat is highly perishable and its long-distance shipment required a network of particular physical assets - refrigerated rail cars, refrigerated storage, and wholesale marketing. ${ }^{10}$ In addition, the trade required managerial coordination of the arrival of supplies to particular markets, since storage time was strictly limited. ${ }^{11}$ The packers owned the specialpurpose refrigerated rail cars, in which the railroads had been uninterested because of their highly specific nature, and the refrigerated warehouses that lacked alternative uses at the time. They also established the distribution networks in the principal markets that successful centralized slaughter and shipment of refrigerated meat required. Chicago-killed chilled beef was a new product that needed skillfully controlled marketing all the way to its final purchase by consumers. Quality control though proper storage and careful attention to storage life was essential. The firms needed to maintain steady supply to develop acceptance of the new product, but at the same time they needed to avoid gluts of perishable beef - which either had to be sold at low prices or be discarded because of spoilage. The big Chicago packers' refrigerated beef business depended on efficient distribution networks and they retained them under their direct control. The network's high fixed costs were the principal source of concentration.

\footnotetext{
${ }^{8}$ Aduddell and Cain, "Public Policy"; and Yeager, Competition, chapter 3.

${ }^{9}$ Economic Institutions.

${ }^{10}$ See Goodwin, Grennes, and Craig, "Mechanical Refrigeration," for an analysis of refrigeration on market integration in America with special reference to butter.

${ }^{11}$ Superior beef is improved in flavor by an aging process. This suggests that the time in transit might even be a benefit. In fact, however, aging involves hanging the carcass in carefully controlled refrigerated conditions for between one and two weeks. These conditions could not be met during nineteenth-century transportation. See Epley, "Aging Beef."
} 
The international meat trade became concentrated for similar reasons of asset specificity, although there were some important differences, particularly in the ownership of the means of transportation. The ships on which meat and cattle traveled were not integrated into the packing companies, but long-term contractual relationships between meat firms and ocean liner companies served similar functions. Contracts with meat firms led to the concentration of North Atlantic shipping into the hands of a small number of liner companies.

\section{CHANGING ORGANIZATION OF THE BRITISH BEEF TRADE}

The British meat trade changed dramatically during the last third of the century as imports grew. ${ }^{12}$ By the 1860 s much of Britain's meat supply already came from abroad, with imported European animals entering traditional distribution channels in Britain. Over the following decades, regulations to contain animal disease and the technological changes originating in the beef trade in the United States transformed the British market.

The transatlantic beef trade was not simply an extension of the development of the American chilled beef trade, despite crucial connections. It is sometimes asserted that globalization of the meat trade required the prior development of mechanized refrigeration, but more North American meat entered the British market in the decades before World War I in the form of live animals for slaughter than as refrigerated meat (see Table 1). ${ }^{13}$ The trade in live animals, of course, depended on late nineteenth-century technology, since it was only viable with reliable fast steam ships, but refrigeration was not the key. ${ }^{14}$

Britain's imported cattle trade changed dramatically when regulations to prevent the import of contagious animal diseases were promulgated following an 1865 outbreak of cattle plague in Britain - the first case in the nineteenth century. ${ }^{15}$ The disease was traced to cattle from continental Europe. It spread throughout Britain when infected imported cattle came in contact with British cattle in live cattle markets in British ports and then infected cattle were taken to other British markets. Cattle losses were heavy. Authorities reacted with regulation, first as Orders in Council and then under the Contagious Diseases (Animals) Act of 1869,

\footnotetext{
${ }^{12}$ Perren, Meat Trade.

${ }^{13}$ See, for example, O'Rourke and Williamson, Globalization, p. 4.

${ }^{14}$ Such ships were available by the 1870 s and their speed and reliability did not change much in the following decades.

${ }^{15}$ Perren, Meat Trade, pp. 106-14.
} 
TABLE 1

BRITISH BEEF IMPORTS FROM NORTH AMERICA, LIVE ANIMALS AND CHILLED MEAT, $1875-1903$

\begin{tabular}{rccccc}
\hline \hline $\begin{array}{r}\text { Five-Year } \\
\text { Average }\end{array}$ & $\begin{array}{c}\text { U.S. Live } \\
\text { Cattle } \\
\text { Exports } \\
\text { ('000) }\end{array}$ & $\begin{array}{c}\text { Meat } \\
\text { Equivalent } \\
\text { U.S. Cattle } \\
\text { ('000 cwt) }\end{array}$ & $\begin{array}{c}\text { Canadian } \\
\text { Live Cattle } \\
\text { Exports } \\
\text { ('000) }\end{array}$ & $\begin{array}{c}\text { Meat Equivalent } \\
\text { Canadian Cattle } \\
\text { ('000 cwt) }\end{array}$ & $\begin{array}{c}\text { U.S. Chilled } \\
\text { Beef Exports } \\
\text { ('000 cwt) }\end{array}$ \\
\hline $1875-1879$ & 41.3 & 298 & 32.8 & 211 & 619 \\
$1880-1884$ & 174.4 & 1,258 & 79.5 & 511 & 629 \\
$1885-1889$ & 226.2 & 1,632 & 111.0 & 714 & 623 \\
$1890-1894$ & 344.7 & 2,486 & 98.6 & 634 & 2,300 \\
$1895-1899$ & 355.3 & 2,563 & 105.4 & 678 & 2,490 \\
$1900-1904$ & 356.7 & 2,369 & 124.8 & 767 & 3,130 \\
$1905-1909$ & 324.7 & 2,157 & 134.2 & 824 & 2,418 \\
$1910-1913$ & 86.1 & 572 & 34.6 & 213 & \\
\hline
\end{tabular}

Sources: Hooker, "Meat Supply." Cattle: British Parliamentary Papers, Annual Statement of Trade, Canadian separated with data from The Statistical Year Book of Canada for 1901. For conversion of cattle to meat, see Hooker, "Meat Supply," pp. 320-21.

that restricted contact between imported and British cattle. Cattle imported from areas where disease was active were prohibited and those from where the disease was known to occur were confined to quarantined areas in designated ports, where they had to be slaughtered within ten days of landing.

The initial regulations were directed at animals from parts of continental Europe and aided the initial development of the transatlantic meat trade, since prohibition of animals from much of Central Europe directed considerable demand towards North America. A modified Contagious Diseases (Animals) Act of 1878 that continued to restrict animals from Europe came into force on January 1, 1879, just as the transatlantic trade began to expand. Initially U.S. and Canadian cattle continued to enjoy unrestricted entry into Britain, but the Privy Council almost immediately (from March 3, 1879) included the United States among the "scheduled countries" whose cattle were allowed only for port slaughter. Canadian cattle, it might be noted, remained free to enter British markets until 1892, and significant numbers of Canadian cattle entered the United Kingdom and underwent further fattening that improved meat quality. This was undoubtedly an advantage and Canadian authorities instituted measures in North America to preserve it. ${ }^{16}$ Nonetheless, the histories of the Canadian and U.S. trades were broadly similar.

\footnotetext{
${ }^{16}$ See the reports on the cattle trade in the Annual Report of the Dominion Department of Agriculture in the Canadian Sessional Papers. See also the testimony of Joseph Colmer to the "Departmental Committee on Transatlantic," Qq. 6819-95.
} 
Before the quarantine regulations, imported live cattle joined the existing distribution network with only modest effect on its organization. Large numbers of cattle from Scotland and Ireland had long supplied English urban markets. To be sure, increasing numbers complicated the logistics of moving and caring for the cattle in transit. Shippers developed more sophisticated organization, but no major organizational changes were required and relatively small firms still competed effectively. The introduction of statutory port slaughter greatly increased the urgency of coordination within the distribution network. Coordination failures had undoubtedly been inconvenient with the large-scale trade in live cattle, but it was physically possible to cope with delay by simply feeding cattle for a few days. Port slaughter eliminated this leeway. Meat imports changed from (relatively) nonperishable cattle to highly perishable meat and the trade came to resemble the dressed meat trade in the United States. Now in England, just as in America, reliable transportation and storage had to always be available and successful pursuit of the business required organization to bring meat to market regularly to avoid gluts and shortages.

The organizational issues of port slaughter had been anticipated by imports of American chilled beef to Britain. By the time American live cattle were restricted to port slaughter at the end of the 1870 s, some 25 thousand tons of chilled American beef was arriving at British ports annually with distribution issues very similar to those in the American dressed meat business, but rather more urgent since the ocean voyage inevitably introduced a week's additional delay. ${ }^{17}$ Not surprisingly, American firms that developed the meat trade in the United States found that their expertise could be applied to similar circumstances in Britain. By the 1880s the leading American firms-Armour, Swift, Hammond, and Morris - were entrenched in the transatlantic beef and cattle trade. In the 1890s they set up British subsidiaries to handle meat distribution and by the early twentieth century, they had moved extensively into wholesale distribution not only in London and Liverpool, but in provincial centers as well and were handling most of the trade. ${ }^{18}$ This dominance paralleled and lagged only briefly behind the same firms' American development and rested on the same foundation. The packers had invented organizational and physical capital that provided reliable transportation and distribution to market meat and large, integrated

\footnotetext{
${ }^{17}$ The passenger liners that carried the chilled meat were crossing in about seven days by the late $1870 \mathrm{~s}$, and perhaps a day less by the end of the century.

${ }^{18}$ Perren, Meat Trade, pp. 164-66.
} 
TABLE 2

AVERAGE PRICE OF VARIOUS TYPES OF BEEF IN GREAT BRITAIN, 1904-1908 (pence per stone of $14 \mathrm{lbs}$.)

$\begin{array}{lll}\text { Scotch long sides } & \text { 1st quality } & 82.5 \\ \text { English } & \text { 2nd quality } & 76.5 \\ & \text { 1st quality } & 77.0 \\ \text { Cow and bull } & \text { 2nd quality } & 71.5 \\ & \text { 1st quality } & 64.5 \\ \text { American and Canadian, Port-killed } & \text { 2nd quality } & 55.0 \\ & \text { 1st quality } & 74.5 \\ \text { American chilled } & \text { 2nd quality } & 68.0 \\ \text { Argentine chilled } & \text { 1st quality } & 66.7 \\ \end{array}$

Notes: Prices for American and Argentine chilled beef were reported separately for fore and hind quarters. Quotations have been combined on the assumption that the hindquarter consisted of 48 percent and the forequarter, 52 percent of a side of beef. The price of chilled American beef hindquarters was 81.5 pence and forequarters 53 pence.

Source: Hooker, "Meat Supply," p. 368-70. For information on meat quotations, see http://www.askthemeatman.com/yield_on_beef_carcass.htm\#breakdown.

firms had advantages fragmented firms could not duplicate. Preexisting managerial expertise drove the American packers to become multinationals. $^{19}$

\section{THE BEEF AND CATTLE TRADE AND NORTH ATLANTIC LINERS}

Savings from transporting dressed meat rather than livestock were a major contributor to the American packers' success. Meat constitutes only about 55 percent of the weight of live cattle and the space savings in shipment is even greater. Once refrigeration was developed, the savings in transportation costs was obvious. Similar cost savings were obviously available in ocean shipping. However, dressed meat did not dominate transatlantic trade because port-slaughtered meat brought higher prices in the British market (between first and second quality English beef, while chilled imported beef sold for 10 to 15 percent less than American port-killed beef). ${ }^{20}$ The average prices of different types of beef in various centers in Great Britain collected by the U.K. Board of Agriculture between 1904 and 1908 are presented in Table 2. Meat from North America to Britain maintained two separate processes - the shipment of chilled meat and the shipment of live cattle-each with different economics. ${ }^{21}$

\footnotetext{
${ }^{19}$ Markusen, "Boundaries," discusses this process from a theoretical perspective.

${ }^{20}$ The fact that Smithfield quotations for the price of hindquarters are available from the late 1880 s, while forequarter quotes are only available from 1904 suggests that the more valuable hindquarters predominated in chilled beef shipments.

${ }^{21}$ Perren, Meat Trade, p. 160; and Hooker, "Meat Supply," pp. 368-70.
} 
Cattle and meat were important for the American railroads, but did not significantly alter the business; in ocean shipping, by contrast, their presence changed the organization of the industry and also very significantly affected freights on other cargoes. Shippers of dressed meat and cattle needed carefully controlled distribution networks with regular deliveries to provide even supply of their perishable product. Shipping companies, for their part, provided specially fitted and often specially built vessels for the carriage of cattle and expensive insulated hold space and refrigeration machinery for meat. Both meat companies and shipowners made investments and commitments whose value depended on continued performance by the other. Despite the interdependence, meat distribution and its ocean shipment did not become integrated within the meat firms as they had earlier in America; the reason stemmed from the difference between railroads and ships. In America, the meat packers owned the specialized refrigerated rail cars central to chilled meat distribution, but they did not, of course, own dedicated railroads. Instead, they contracted locomotion and the use of rail line with the trunk railroad companies. The specific capital in ocean shippingrefrigerated space and cattle accommodations-differed from refrigerated rail cars in that its ownership could not be easily separated from overall ship capital. Ship owning involved large amounts of capital, and refrigerated meat or cattle made up only a part of complex cargos. The Coase-type advantage of transactions cost internalization that led to the packing houses owning refrigerated rail cars was outweighed in Atlantic shipping by costs a packing house would have had to assume to own ships and manage the accompanying complexities of arranging and handling additional cargo. Nonetheless, meat companies and shipowners structured their dealings to ensure continuing relationships that protected the assets of each. From the start of the trade, liner companies and the meat firms negotiated contracts for fixed amounts of shipping space for cattle or meat per week. Annual or longer contracts, with renewal, were the rule. The liner company guaranteed regular space and the meat company agreed to pay for space, whether used or not. ${ }^{22}$ These contracts gave advantages to large ship-owning firms. In shipping units larger than a single ship, companies enjoyed no technological advantage, but the regular, carefully organized shipments required for port slaughter of cattle created organizational advantages for larger units

\footnotetext{
22 "Departmental Committee on Transatlantic." R. F. Leland of the Leland Line (Qq. 39994000), Dunlop in the Allen Line (Qq. 6376; 6388), and Warren of the Warren Line (Qq. 46994705). The "Departmental Committee on Combinations" in 1909 provides similar evidence regarding contracting evidence from Armour (Britain) (Qq. 764; 786-802) and Swift (Qq. 141012). See also Qq. 1934; 5956.
} 
with substantial specialized fleets. Similar shipping contracts for cattle and meat existed between the packers and American railroads, but since the railroads were already large firms, the contracts did not stimulate organizational adjustment.

Although organizational requirement of shipment of chilled meat and port-slaughtered live cattle were similar, from a shipping point of view, the two were almost entirely distinct. Refrigerated meat was carried by the passenger or mail liners that were the fastest ships on the North Atlantic. From the 1870s they installed refrigerated space in which they carried fresh beef. These meat cargoes contributed usefully to the liners' freight earnings, but quantities involved were a small part of these ships' business that centered on regular passenger service. In 1877 White Star steamers carried about 1,200 quarters of beef each trip. ${ }^{23}$ That beef only weighed a little over 100 tons. Similarly, in 1893, the White Star Britannic sailed on August 22 with 161 tons of fresh meat and the Cunard Etruria sailed on August 25 with 182 tons. ${ }^{24}$ These liners focused on passengers and had cargo capacities of about 2,000 tons.

Live cattle, unsurprisingly, were not carried on the mail steamers, since cattle were incompatible with these ships' main business of luxury passenger transportation. ${ }^{25}$ Instead, new liner companies emerged providing regular cattle carriage in specialized vessels. There were no technological constraints preventing these ships from also carrying refrigerated beef-except the cost of installing refrigerated capacity which, unlike the case of passenger liners, had no complementary use in food storage. Some experimented with carrying chilled beef and cattle together, but none chose to do so on a continuing basis. ${ }^{26} \mathrm{R}$. F. Leland of the Leland Lines, one of the principle liner companies, testified to the 1890 British Departmental Committee on the Transatlantic Cattle Trade on experiments in the carriage of chilled meat with cattle:

I have a contract with the Hammond for five ships, each of them can carry 3,500 quarters or 3,600 quarters, that is about 900 cattle. The same vessels will carry about the same number of live cattle, making a total of about 1,800 every ship. The contract was for three years, with the option to them to cancel at 12 months on paying $£ 1,000$ per ship. It is only within the past few weeks I have received a letter dated 29 October this year [1890] in which the chairman of

23 "Select Committee on Cattle Plague," Q. 8644.

${ }^{24}$ New York Shipping and Commercial List, 2 September 1893.

${ }^{25}$ Some liners to Canada carried both passengers and cattle.

${ }^{26}$ Leland's 1890 testimony to the "Departmental Committee on Transatlantic," Qq. 39994000. See also the evidence of Dunlop regarding the Allen Line, which was building experimental ships but "already we have grave doubts of the advantage of it" (Q. 6376). John Montgomery of the Dominion Line (Qq. 6169-80) and W. D. Hill of Allan and Hill Lines (Qq. 4396-4400) make similar comments. He also comments that "the refrigerators are fitted up by the exporters of the meat" in a way rather similar to the packing houses' ownership of refrigerated rail cars. 
the company writes to me and says that it is utterly impossible to carry on the trade because the live cattle have completely knocked them out of the market, owing to their getting a better price... The chairman of the Hammond Company writes to me, "An entire change has taken place since our last interview, and instead of, as in the past, the dressed beef shippers having the advantage over live cattle shippers, the case is reversed, and the live cattle shipper is in the better position of the two, and with the price of the London slaughtered American beef fully two cents per pound above refrigerator, even when delivered in the best possible condition, the outlook is very discouraging for the dressed meat business."

The fact that the cattle liners did not develop the chilled beef trade, but the passenger liners did - in quantities that around the turn of the century provide nearly the same amount of meat as the live cattle tradeshows that that the passenger liners were willing to enter into contracts at freight rates that did not cover the extra costs that the cattle liners would have had to incur. They were willing to accept these contracts because the refrigerated capacity had other uses and cattle were not an alternative.

The cattle contracts had impact far beyond meat shipment itself because they committed ships to regular liner sailings, and while the ships carried maximum cattle loads, the animals did not exhaust the vessels' carrying capacity. Consequently, the liners sought other available cargo. So long as liner capacity was modest relative to the shipment of other cargoes, the liners could engage these cargoes at rates close to the freight rates charged by tramps carrying full cargoes. By the beginning of the 1880s, however, the capacity of liners on the North Atlantic had become so great that they could carry all American exports between the principal liner ports. When this happened, liners bidding for grain and provisions on key routes lowered freight rates below those that tramp steamers would accept and the liners dominated.

\section{LINER CAPACITY AND FREIGHT RATES}

The economics of North Atlantic shipping throughout the nineteenth century was complicated and freight rates on different routes and commodities did not follow a common time path. In particular, the grain rate from New York to Liverpool, which is often used as a general indicator of North Atlantic freights and sometimes freight rates generally, fell more rapidly in the late nineteenth century than other rates. Rates on other exports on principal liner routes fell somewhat less than grain rates, but noticeably more than rates to other destinations. The cattle trade caused the variation. Liners, both passenger vessels and cattle ships making regular scheduled sailings, came to dominate much of 
North Atlantic shipping by the 1880 s. On one hand, massive European emigration led to expanded passenger liner operations. Intermediate passenger liners with immigrant accommodations, economical operation, and substantial cargo capacity became increasingly important in the carriage of cargo. At the same time, new lines emerged focused on cattle shipment. Cattle ships possessed extensive deadweight capacity in their holds and actively sought heavy freight, such as grain, to fill up. The cargo capacity of these cattle liners transformed the Atlantic cargo trade in the 1880s. Thomas Ismay of the White Star Line noted in 1890 that being in the passenger business, he would be happy to see the cattle trade disappear because:

Previously, we used to get very much higher freights upon the dead weight and other cargo by the liners, but since the introduction of the carrying of cattle it has become such a large trade, and so many ships are engaged in it, and ships of such a very fine class, that they now compete with us for the dead weight, which is necessary to give stability to those ships. We should have been very much more in pocket if there had never been a beast brought over the Atlantic...We have got the passenger trade, and where we used to be making very large freights for our cargo we make very little now, in fact we are bringing grain over freight free. The ships wanted ballast, as so they brought grain freight free. ${ }^{27}$

The joint production of various shipping services - that the production of one necessarily creates others - often is crucial in understanding freight rates. First, shipment on, say the North Atlantic, requires a round trip even if no cargo is available on one leg of the voyage. Thus, eastbound shipment, as that of cotton in the antebellum years, creates westbound capacity. Second, disparity between bulk and weight also creates jointness. Light cargoes, such as cotton, will fill a ship, but leave it with excess buoyancy for optimal navigation. The ship will be willing to take heavy cargo at low rates. Alternatively, a heavy cargo, such as iron or ore, will exhaust a ship's buoyancy, while it still has empty space and light cargo will be sought. Cattle ships introduced an important additional jointness. A ship carrying as many cattle as it could still had extensive capacity available to carry heavy bulk cargo.

When cargo capacity is jointly produced, the freight rates on individual cargoes depend on an interaction of the demand for the variously jointly produced capacities. In the late nineteenth century, outward and homeward passenger and animal capacity and space for various other types of cargo were available on each voyage. In the long run, competition that

\footnotetext{
27 "Select Committee on Cattle Plague," Qq. 638-39. He ends with the comment that, "[O]ne shipowner actually carried the grain back to America. He did not land it here, but used it as ballast.” This assertion seems improbable given that wheat was worth some £2 per quarter in Britain in the late 1880 s.
} 
eliminates excess profits will equate the total revenue from the entire voyage to its total costs. In the short run, entire voyage revenue will be compared to what could be earned in other trades where marginal ships could be shifted. Freight rates for each category of cargo will then be determined by the price that shippers of various commodities are willing to pay for the various available spaces. It is highly unlikely that the competitive process will result in each type of cargo paying its proportional (either in weight or volume) share of the total voyage costs. In the best known and simplest case, if homeward cargoes are more plentiful, homeward freights will exceed outward.

In the nineteenth-century North Atlantic, the shares of voyage costs paid by various cargoes altered. Throughout the century, eastbound cargoes predominated. Even late in the century, although westbound demand increased as the United States' raw material imports increased, and more importantly, immigrants demanded shipping space, eastbound cargoes still substantially exceeded westbound cargoes and the excess capacity kept westbound freights low. The market changed, however, because liners' key cargoes - passengers and live cattle-left lower hold capacity eastward. Passenger liners, particularly those specializing in immigrants, provided some of this capacity, but the export of live animals that grew rapidly after the late 1870 s provided most.

Passengers and live animals are very light and, more importantly, only occupy a portion of a vessel and so leave ships with space and buoyancy. Cargoes of approximately 40 cubic feet per ton simultaneously weigh down and fill a ship. A live steer, with feed and fittings to insure arrival in good condition after its ocean crossing, weighed about 1500 pounds and required approximately 120 cubic feet. In practice, about half of the cattle were carried as deck cargo in specially constructed pens or in other parts of the vessel (spar deck areas) not available for the carriage of other cargo, so a ton of cattle effectively occupied about 80 cubic feet of cargo capacity. ${ }^{28}$ More crucially, cattle could only be carried on upper decks because adequate ventilation could not be provided in the lower hold. Passengers, of course, even immigrants, received much more room than cattle and could also not be carried in lower hold space. So a passenger ship or a cattle ship had extensive space and buoyancy available after full cargoes of cattle or passengers

\footnotetext{
${ }^{28}$ Plimsoll, Cattle Ships, provides highly critical descriptions of cattle ships. It also contains some accessible photographs, albeit of inferior ships, of how cattle were shipped. Plimpsoll's discussion should be supplemented by the testimony to the "Departmental Committee on Transatlantic," that his pamphlet spawned and which provides extensive details on conditions and on the fitting out of cattle ships of cattle shipment, which contradict many of Plimsoll's assertions.
} 


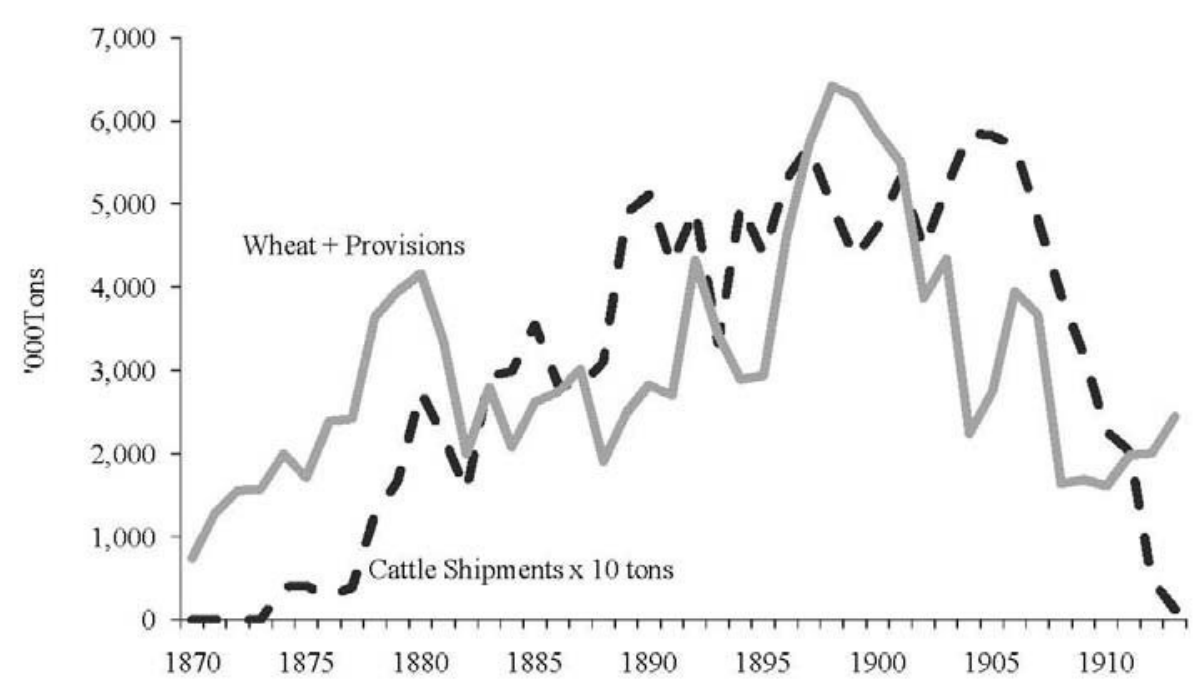

FIGURE 2

SHIPPING CAPACITY ON CATTLE VESSELS VS. GRAIN AND PROVISION SHIPMENTS

NORTH ATLANTIC, 1870-1913

Note: Sheep are combined with cattle (10 sheep $=1$ head of cattle), and the scale for cattle is chosen so that 1 head $=10$ tons of grain. See the text for details.

Source: The data are compiled from British import statistics. Wheat from American Atlantic ports is from the Statistical Abstract of the United Kingdom. The meat shipments are put together from the Annual Statement of Trade.

had been loaded. Heavy cargo to fill that capacity could be engaged, increasing revenue so long as the freight exceeds the modest extra voyage expenses.

During the 1880s, live cattle imports into the United Kingdom from North America grew to some 400,000 head per year. Liner companies (c.f., Warren Line, National Line, Hill Line, Allen Line, with others such as the Inman and Cunard Lines, with some involvement) carried nearly all the cattle. The average cattle ship was about 2,000 net register tons and carried 300 to 500 head of cattle per trip. This ship had deadweight cargo capacity of about 4,000 tons, while 500 cattle and their fittings would have weighed less than 500 tons. Thus, every 100 cattle carried was accompanied by capacity to carry between 700 and 1,200 deadweight tons for other cargo.

Figure 2 provides an indication of the timing of the growth of liner lower hold capacity. It focuses on cattle, since it is here that the dramatic change occurred. The figure compares the numbers of live cattle (and the small numbers of sheep aggregated as 10 sheep $=1$ cattle, as was the usage of the trade) with the quantity of grain and provisions imported into 
Britain from U.S. and Canadian Atlantic ports. Data in the figure are scaled so that a head of cattle has the same scale as 10 tons of grain and provisions (the capacity that accompanied each animal on a cattle ship) in order to compare the evolution of deadweight capacity of cattle ships with demand for cargo. The comparison is not exact. Ten tons is at the high end of capacity per head of cattle, but not all bulk exports were on liner routes. Furthermore, passenger liners added some 20 percent additional eastbound capacity. Cargo capacity accompanying livestock exports increased rapidly in the late 1870 s and then surpassed the quantity of grain and provisions exports. Competition among these liners drove down freight rates on bulk exports suitable for liner cargo capacity to rates below those tramp ships would accept.

Passenger vessels added additional eastbound bulk capacity. To be sure, and increasingly as the century progressed, the great luxury liners of the Cunard, White Star, and Hamburg America lines were luxury hotels afloat and neglected cargo capacity, although they did provide extensive immigrant steerage accommodation. Nonetheless, newspaper listings of exports, probably incomplete, show considerable cargo capacity on even the premier passenger liners. For example, on Aug. 29, 1882 Cunard's Serbia, one of the luxury liners on the main New York service built the previous year, departed New York for Liverpool. The New York press listed bulk cargo loaded for the voyage. Principal among them were the following: ${ }^{29}$

$\begin{array}{ll}\text { Wheat } & 28,539 \text { bushels } \\ \text { Flour } & 1,495 \text { sacks } \\ \text { Cotton } & 1,606 \text { bales } \\ \text { Bacon } & 220,127 \mathrm{lbs} . \\ \text { Hams } & 47,625 \mathrm{lbs} . \\ \text { Tallow } & 34,580 \mathrm{lbs} . \\ \text { Lard } & 5,600 \mathrm{lbs} . \\ \text { Cheese } & 86,836 \mathrm{lbs} .\end{array}$

Five to ten passenger liners a week left American ports. The Cunard records show about 125,000 tons of eastbound cargo in the 1880s on two voyages a week. By the early twentieth century, that figure increased to about 250,000 tons. ${ }^{30}$ Thus, passenger liners provided between a quarter million and a million tons of bulk cargo capacity annually in addition to that provided by the cattle steamers (an augmentation of a fifth of the cattle ship capacity).

\footnotetext{
${ }^{29}$ New York Shipping and Commercial List, 30 August 1882 and 2 September 1882.

${ }^{30}$ These are in the voyage accounts of the company in the Liverpool University Library.
} 


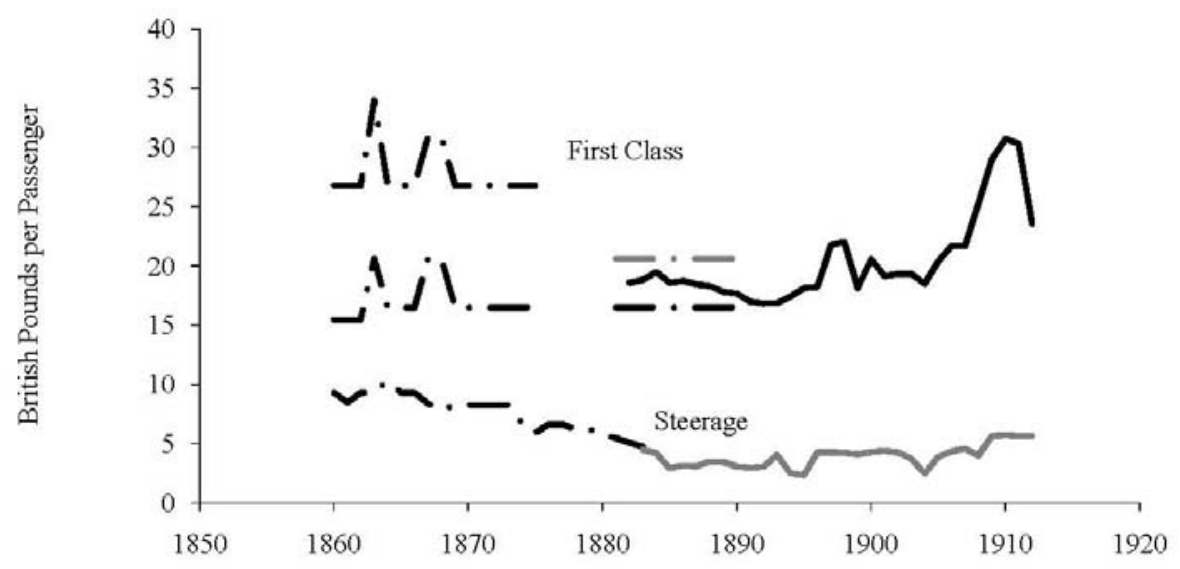

FIGURE 3

PASSENGER FARES, 1860-1913

Source: Solid lines: Cunard westbound earnings per passenger, Cunard Voyage Accounts, University of Liverpool Library. Broken lines: Hamburg America Lines, range of first-class fares and steerage per passenger. See Heffer, Le Port.

Detailed investigation of liner economics can usefully start with information on the freight rates on "primary" cargoes. Passenger rates are presented in Figure 3. Unfortunately, no long time series of meat and animal freight exists, but a general outline can be pieced together from various sources. When the live cattle shipments began in the late $1870 \mathrm{~s}$, freight rates were $£ 7$ per head. Initial profits disappeared by the early $1880 \mathrm{~s}$, when the rate stood at between $£ 3.5$ and $£ 5$. The rate continued to fall, reflecting technological improvements and shipping depression, to around $£ 3$ in the late $1880 \mathrm{~s}, £ 2$ for most of the 1890 s, and around 30 shillings after the turn of the century. ${ }^{31}$ Chilled meat was carried almost exclusively on the major passenger liners, which shipped cargoes of between 150 and 200 tons per voyage. Sporadic freight quotes indicate that in the late $1870 \mathrm{~s}$, rates were between 30 shillings and 55 shillings per carcass or 40 cubic feet; in 1890, 20 shillings; 1892, 24 shillings; and $1897, \$ 5$ or $\$ 6$ (21 shillings to 25 shillings) for four quarters of a steer. $^{32}$

The coexistence of two separate supplies of American beef to the British market in the form of chilled and live cattle requires some

\footnotetext{
${ }^{31}$ Fairly long series are available from both the British Consul in Boston and from the agents of the Canadian Dominion Department of Agriculture in Britain. These cover rates are from Boston and Montreal, respectively. These were two of the most important exporting ports. See "Departmental Committee on Combinations," pp. 304-06.

32 "Select Committee on Cattle Plague," Q. 6180; and "Canadian Department of Agriculture, 1893," p. 44.
} 
comment. The equilibrium that divided the beef trade rested on both the relative freight rates on live and dead beef and the relative price of chilled American dressed meat and port-killed meat. Figure 1 shows that imported meat had a significant impact on the relative prices of different grades of meat in Britain with the price of low quality beef falling much more than higher quality. ${ }^{33}$ Similarly, the relative prices of portslaughtered and chilled American beef were subject to variation (see Table 2). Relative freight rates were also free to move. As we have seen, cargo liners experimented with shipments of chilled beef in the late 1870 s and early 1880 s, but discovered that it did not pay because passenger liners were willing to carry chilled beef at freight rates that covered their marginal costs, but were too low to attract cargo liners that carried live animals.

\section{THE EFFECT OF LINER CAPACITY ON BULK EASTBOUND ATLANTIC FREIGHT RATES}

Before the $1880 \mathrm{~s}$, liners had filled the capacity that cattle and passengers made available in a freight market where tramp steamers were marginal carriers. The tramps' presence kept liner berth rates close to freight rates on tramp routes in a global shipping market, although, at a somewhat lower freight rate to compensate for the rapid loading and unloading the liners required. The growth of cattle shipments in the early 1880s expanded liner capacity beyond the volume of bulk cargoes offered on their routes. As liners competed for cargoes, freight rates fell below the earnings tramps could obtain elsewhere and North Atlantic berth rates disconnected from the world market for tramp shipping. Competition among liners with aggregate capacity in excess of the cargoes on offer tended to drive berth rates to the marginal costs of their handling. Grain was the most important of the berth cargoes and the most affected. Liners shipped large quantities on so-called "berth terms" from New York and other ports. The grain was shipped in less than shipload quantities with the vessel deciding the quantity, on terms that required the grain be loaded and unloaded with exceptional dispatch to suit the liners' schedules.

The rate per bushel of grain on berth terms from New York to Liverpool is the most readily available transatlantic freight rate (see particularly the U.S. Statistical Abstract) and its rapid decline has been widely used to represent Atlantic rates generally and often shipping generally. This rate, however, was exceptional and its decline far from

\footnotetext{
${ }^{33}$ It should be noted that Hooker, "Meat Supply," p. 335, expressed the opinion, but offered no evidence, that the relative price shift indicated a change in definition of inferior beef.
} 


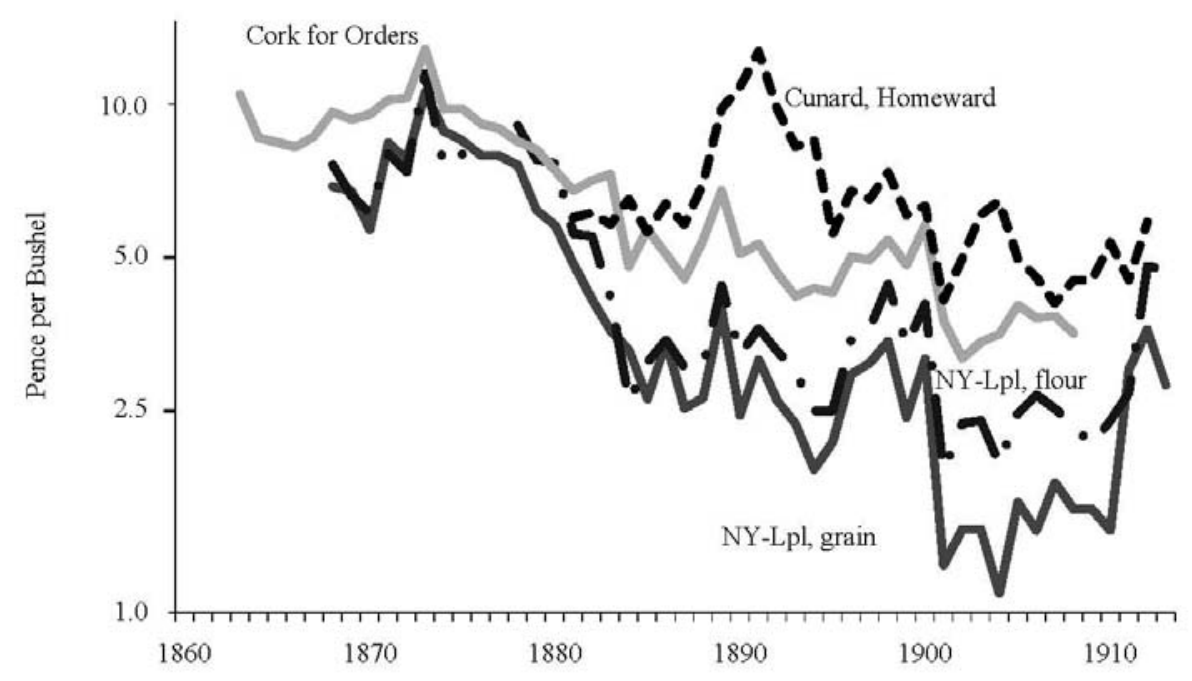

FIGURE 4

VARIOUS NORTH ATLANTIC FREIGHT RATES, 1863-1913

Source: See Appendix Table 1.

representative. Rates from other ports and on other commodities decline less rapidly. Figure 4 displays (on a semi-log scale) a sample of eastbound Atlantic freight rates. ${ }^{34}$ The rates for whole cargoes of grain on "Cork for orders" charters to northern European ports and for flour on "berth terms" from New York to Liverpool have both been taken from published sources. The records of the Cunard Company make it possible to construct a series for average earnings per ton of cargo on eastbound voyages of passenger liners.

Contemporaries realized that berth rates, particularly grain from New York to Liverpool, were subject to special influences. A leading American authority noted:

A distinction needs to be made between the regular cargo rates of ocean lines and their so-called "berth cargo" rates. The berth cargo of lines consists mainly of commodities such as grain or case oil, which line vessels regularly carry to fill surplus cargo spaces not taken up by traffic that they carry at regular line rates. Berth cargo rates are frequently reduced to a low level at large ports, such as New York, which are served by many regular lines. At times such cargoes are carried in lieu of ballast, and their rates are regarded as profitable so long as they yield anything over and above the immediate costs incurred in handling them. ${ }^{35}$

\footnotetext{
${ }^{34}$ Details of these and other Atlantic freight rates may be found in Harley, "North Atlantic Shipping."

${ }^{35}$ Johnson and Huebner, Principals, p. 318.
} 
The extent to which large available tonnage and limited berth cargo could depress freights rates, attempts at agreement among the liner companies notwithstanding, is illustrated by extreme cases. The freight report of New York Shipping and Commercial List for June 3, 1882, for example, reported: "An indication of the depression is afforded by the fact that the Liverpool steamers have taken grain free of charge in preference to buying ballast." The annual report of the British Consul in New York for 1901 contains a similar report. ${ }^{36}$ In New York, shipments to Liverpool after the early 1880 s were dominated by liners throughout the season. The extent of liner domination to other destinations varied with the volume of liner traffic and the season.

The New York to Liverpool grain traffic benefited particularly from liner capacity. The passenger liners sailed almost exclusively to Liverpool. Cattle liners were less dependent on a single port, but many ships went to Liverpool (strictly Birkenhead across the Mersey). The remaining cattle ships went mainly to Glasgow and London (Deptford), with a small number going to Bristol and Hull. In contrast, only about half the exports of American grain to British ports went to Liverpool, Glasgow, and London combined. Second, grain was particularly desirable as a filling cargo because it was readily available in bulk and by the $1880 \mathrm{~s}$, elevators in exporting and importing ports allowed liners to load and discharge with dispatch and without interrupting their scheduled sailings or incurring additional expenses of delay. Consequently, grain freights on primary liner routes were particularly low. This in turn, of course, drew a larger proportion of grain traffic to these ports than would otherwise have been the case.

The peculiarity of the berth rate can be gauged by a comparison with freights on the considerable quantities of grain carried from North Atlantic ports to Europe in tramp steamers, often large recently built vessels. Although liners came to carry the majority of East Coast grain exports, they did not completely displace tramp steamers. In 1895,78 million bushels of wheat and corn were exported from North Atlantic ports of the United States. Some 32 million bushels were carried as berth cargoes from New York and an additional 30 million as berth cargoes from other ports. The more than 16 million bushels remaining were carried as full cargoes; nearly 8 million bushels of that from New York. This grain was carried at the higher "Cork for orders" freight rate. In 1896 when exports were considerably larger, 123 million bushels were exported. New York berth cargoes still made up 32 million bushels, while some 51 million bushels were carried as berth cargoes from

\footnotetext{
${ }^{36}$ Annual Report of British Consul, New York, 1901, p. 20.
} 
other North Atlantic ports. The remaining 40 million bushels were carried as full cargoes at the "Cork" rate from various ports. ${ }^{37}$ The charter rates were paid from U.S. to European ports, where savings on internal shipment within the United States or Europe offset the extra ocean costs. The cargoes were carried under a so-called "Cork for orders, charter party" in which the shipper had the option to chose any of a range of northern European ports as a destination, and then informed the vessel of its choice when the ship arrived in Ireland. (Alternatively, the shipper receives a discount on the freight if a port was chosen on departure.) The rates in these charter contacts indicate the overall opportunity cost of North Atlantic shipment (i.e., the entire costs of a vessel in competition with other tramp trades).

\section{AN ECONOMETRIC INVESTIGATION OF NORTH ATLANTIC FREIGHT RATES}

The assertions regarding the development of North Atlantic berth rates made in the previous section can be investigated with greater rigor statistically. We examine two propositions: first, whether the "Cork for orders" rate can be taken as primarily determined by the state of the global market for tramp shipping; and second, the proposition that the New York-Liverpool grain berth rate responded to liner cargo capacity.

There is no entirely satisfactory index of late nineteenth-century global shipping rates, and construction and interpretation of such an index is bedeviled by problems arising from the joint product nature of most shipping and beyond the scope of this article. An alternative is to compare the "Cork for orders" rate to the freight rate on wheat exports from Odessa, the main Russian Black Sea port, and an important tramp shipping route, where no changes comparable to the liner development in the North Atlantic occurred. ${ }^{38}$ Between 1868 and 1908, the Cork rate and the Odessa rate were closely related and with correlation of 0.918 . Equation 1 is a simple regression of the "Cork for orders" rate on the Odessa rate from 1868 to 1908 (without a constant). An Engle-Granger test reveals that the equation is a cointegrating relationship between the two nonstationary freight rate series. ${ }^{39}$

\footnotetext{
37 "Grain Trade of the United States," Monthly Summary of Commerce and Finance, p. 1987.

${ }^{38}$ Freight rates from the Black Sea, standardized to rate from Odessa are available in Harley, "Coal Exports," pp. 336-37. Since the rates reported there refer to a crop year ending in July of the year, lagged values have been used in these regressions.

${ }^{39}$ An additional estimation including a constant and a time trend increased the adjusted $R^{2}$ very slightly.
}

$($ Cork for Orders $)=3.75+0.234($ Odessa $)-0.043$ time

(2.83) (5.75) $\quad(-1.58) t$-ratio. 
Estimation of a vector error correction model reveals that both the Cork rate and the Odessa rate adjusted rapidly to divergence from the longrun relationship. ${ }^{40}$

The principal hypothesis in this article is that development of the cattle trade changed the relationship between the "Cork for orders" rate (represents the overall conditions of the global shipping market) and the berth grain rate. Discussion of liner capacity above suggests that a shift could be expected in 1882 (see Figure 2). A Chow-test on a simple firstorder auto-regression of the ratio of the berth rate to the Cork rate on its lagged value confirms a shift occurred. ${ }^{41}$ However, examination of the time series properties of the residual from the test equation showed continued nonstationarity. Consequently, the time series was examined further for breaks of unknown timing using the procedures outlined in articles by Jushan Bai and Bruce Hansen. ${ }^{42}$ The first pass Andrews supWald test yielded results are summarized by the dotted line in Figure 5. They confirm the presence of the break in 1882, but also suggest a further break around 1901. Application of a sequential test on the subseries from 1882 to 1908 (shown by the dashed lines in Figure 5) confirmed a downward break at 1901. Finally, a test on the subsample 1868-1901 strongly confirmed the structural break at 1882 .

The final time series representation of the ratio of the Berth rate to the "Cork for orders" rate (1868-1908) took the following form (where $\operatorname{dum}_{1882}$ takes a value of 1 from 1882 on and dum 1901,1 from 1901, and $t$-statistics in parentheses): ${ }^{43}$

\footnotetext{
${ }^{40}$ The adjustment coefficient on the Cork rate indicated that 27 percent of the divergence was corrected in the following year, while that on Odessa indicated 80 percent correction.

${ }^{41}$ The regression results for the period 1868-1908 were as follows:

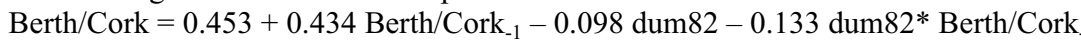
None of the individual coefficients except the constant was significant, but for the joint significance of the break variables yield an $F(2,36)$ of 7.355 , which indicated a $p$-value for the null of no shift of 0.002 .

${ }^{42}$ Bai, "Estimation of Change Point," pp. 551-63; and Hansen, "New Econometrics," pp. $117-28$

${ }^{43}$ The insignificant individual $t$-statistics are present despite the clear structural breaks indicated in Figure 5. The break variables are jointly significant.
} 


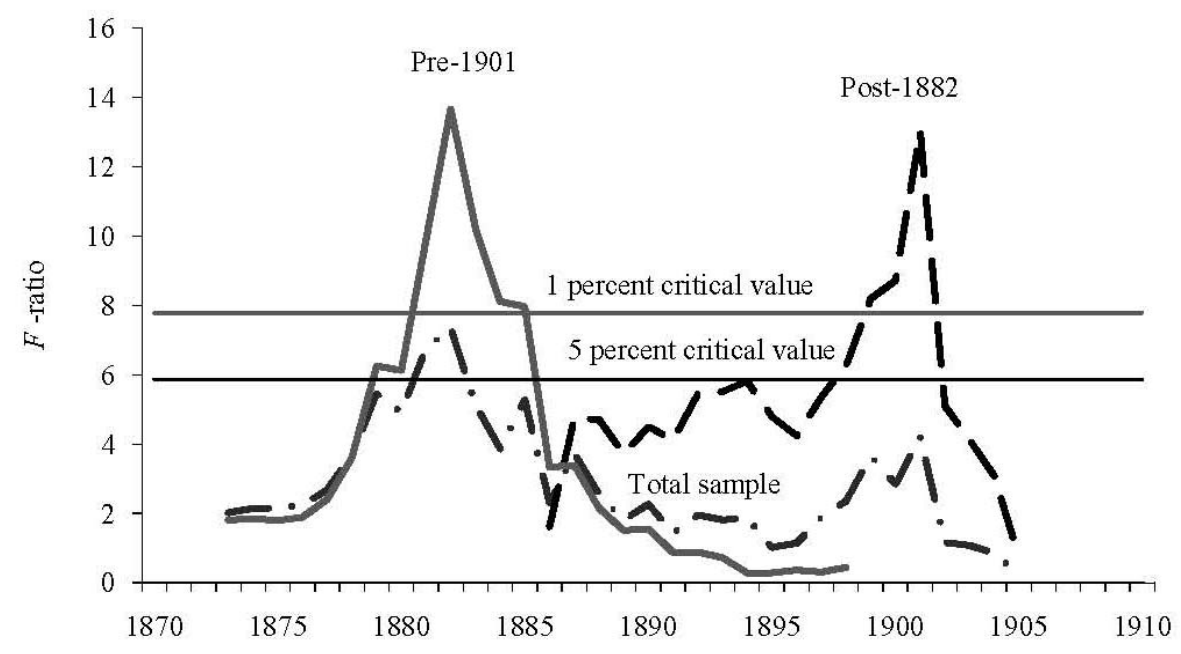

FIGURE 5

TESTS FOR STRUCTURAL BREAKS IN RATIO OF BERTH TO CORK FOR ORDERS RATES

$(F$-STATS $)$

Source: See the text.

Berth $/$ Cork $=0.336+0.566$ Berth $/$ Cork $_{t-1}+0.396$ dum $_{1882}-0.905$ dum $_{1882}{ }^{*}$ Berth $/$ Cork $_{t-1}$ (1.58) (2.14)

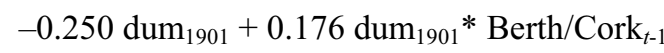

$(-0.89) \quad(0.28)$

The estimated equation does not transparently reveal the extent of the breaks, but calculation of the steady state ratio of the Berth rate to the Cork rate for the three periods yields the following:

$\begin{array}{ll}\underline{\text { Period }} & \underline{\text { Berth/Cork }} \\ \text { Before } 1882 & 0.77 \\ 1882-1901 & 0.55 \\ \text { After } 1901 & 0.41\end{array}$

The relationship between the Berth rate and the "Cork for orders" rate was investigated further. Inclusion of the ratio of cargo capacity to American exports of bulk cargoes indicated that once the breaks identified were included, variations in the relationship between cattle shipments and other exports did not increase the explanatory power of the estimates. Once liner excess capacity had changed the nature of the 
market, marginal costs of carriage rather than variations in cargo volume determined the freight rate.

The econometrics, although indicating greater complexity than originally supposed, strongly supported the hypothesis that the North Atlantic berth grain rate shifted downward when liner capacity became sufficient to carry all eastbound cargo in the early 1880s. The subsequent break in the time series in 1901 requires further investigation. The date coincides with the formation of the International Mercantile Marine Company (IMM) - an attempt by leading shipping companies, aided by Morgan finance, to organize a North Atlantic shipping trust. Ironically, the trust appears to have caused a downward shift in berth rates. Perhaps this decline in berth rates was compensated by higher rates on other cargoes, but the disastrous financial result of the IMM suggests otherwise. $^{44}$

\section{OVERALL NORTH ATLANTIC FREIGHT RATES}

Liner-induced changes in berth rates resulted in a range of North Atlantic freights that defy easy generalization. ${ }^{45}$ The tramp "Cork for orders" rate declined less than the Berth rate; at the other extreme of shipping organization, Cunard liners' average earnings per ton of cargo were essentially unchanged between the early 1880s and the First World War. ${ }^{46}$ The Cunarders carried a variety of cargoes and catered to high value cargoes willing to pay high freights for special care and rapid delivery. Refrigerated cargoes, particularly fresh beef, made useful contributions to freight earnings. Grain, as a filling up cargo, also affected the average, but the decline in its rate affected average earnings only modestly.

Berth rates to Liverpool on flour and provisions declined somewhat less than the grain rate because carriage of these commodities was less convenient for the liners and the rates were not so depressed by competition for filling up cargoes. Rates on flour and provisions from New York to various European ports moved fairly closely together, at levels substantially above the grain rate, although varied somewhat with market conditions because grain rates were more responsive to prosperity of shipping in general. The rate on flour was about a quarter above the rate on grain in the $1880 \mathrm{~s}$, as much as two-thirds above in the shipping depression of the early twentieth century and still a third above when prosperity returned in the last years before the war. Provisions-largely

\footnotetext{
${ }^{44}$ See Carosso, Morgans, pp. 481-86; 491-93; and Navin and Sears, "Study in Merger."

${ }^{45}$ For a more detailed discussion of these freight rates, see Harley, "North Atlantic Shipping."

${ }^{46}$ Cunard Company Records, University of Liverpool Library.
} 
bacon, ham, and cheese - to Liverpool were usually between a third and a half higher than flour, while provisions to other ports were higher again by about the same proportion. Berth rates on grain to other ports were also higher than those to Liverpool. Rates from New York to Glasgow and London, the other two main liner routes, exceeded the rate to Liverpool by about 10 percent. Rates on routes with less intensive liner traffic were higher still. Less comprehensive data on the exports of other U.S. ports are available. Boston was the largest single port for the export of live cattle and, at least at the end of the 1890s, shipped grain exclusively as berth cargo. Here berth grain rates were very similar to, and perhaps even lower than, New York's. The berth rate from Baltimore to Liverpool was some 10 percent higher than the rate from New York. ${ }^{47}$

The range of freight rates, commodities, and destinations makes it difficult to provide a summary assessment of the overall effect of liner capacity on North Atlantic freights. New York to Liverpool was certainly the single most important route and liners carried large amounts of grain on this route, much of it attracted by low rates, but its importance should not be overemphasized. Glasgow, London, Bristol, Antwerp, Rotterdam, Le Havre, and Hamburg were important alternative liner destinations. Between 1873 and 1900, only about 15 percent of the wheat and corn exported from New York was destined for Liverpool. An additional 43 percent went to other U.K. ports; London and Glasgow, the other two main liner ports, together taking slightly more than Liverpool. Most of the balance of New York's grain went to other European ports. ${ }^{48}$

\section{CONCLUSION}

Globalization of Britain's meat supply was an important feature of the late nineteenth century. The intercontinental meat trade, although similar to the more extensively studied grain trade at a superficial level, differed in important ways. As in recent globalization, it was increasingly dominated by large multinational corporations. In addition, the meat trade had important effects on North Atlantic shipping, where it enhanced the dominance of liner companies and significantly altered the economics of freight rates, driving down the rates on American grain in particular.

\footnotetext{
47 "Grain Trade of the United States," Monthly Summary of Commerce and Finance, p. 1987; "Statistical Appendix," Annual Reports of the New York Produce Exchange; and Andrews, "Ocean Freight Rates."

48 "Grain Trade of the United States," Monthly Summary of Commerce and Finance, pp. 197578, 1986, 2016-19.
} 
The giant firms of the American "meat trust" grew through vertical integration of slaughter and meat distribution in response to the perishability of slaughtered meat that required investment in innovative refrigerated shipment and storage and careful coordination of distribution from slaughter to final sale. They brought this organization to the transatlantic trade. On the Atlantic, the specialized shipping capital could not be separated from the ship as a whole and consequently was not owned by the packers. Instead, long-term contracts ensured orderly distribution. Contractual regular shipments increased the returns to large-scale enterprise in shipping, where purely technical economies beyond the single ship were small and liner companies owning substantial fleets committed to regular sailings became dominant.

Rather surprisingly, two separate forms of trade in meat from America to Britain - slaughtered beef shipped in refrigerated holds on passenger liners and live cattle for slaughter in Britain - persisted. The trade in slaughtered beef arose as an extension of the packing houses' domestic American trade and followed similar trends. The American firms' expertise in the new technology and the management of distribution provided them with knowledge that supported multinational operations. However, more live cattle than slaughtered beef was shipped and the Chicago packers dominated this business as well. Their success rested on British animal health regulations that required port slaughter of imported cattle so that the distribution of the meat from the live animals also required the technology and management expertise that the American firms had developed.

The meat trade also altered the complex economics of the freight market. In the early 1880 s, liners came to dominate the shipment not only of goods that required prompt distribution, but also of bulk commodities. Passengers and cattle justified liner organization, and the ships on which they traveled had extensive lower hold capacity that liner companies could profitably sell at rates below those attractive to tramp shipping, since the primary cargoes paid a disproportionate part of the voyage's fixed costs. The extreme impact of liner capacity was on the berth rate for grain from New York to Liverpool-which is usually taken to indicate the course of U.S. export freight rates. However, this rate was particularly reduced by liner capacity. The "Cork for orders" rate on full cargoes of grain, which continued to carry much of America's grain exports, declined about 44 percent between the early 1880 s and the early $1900 \mathrm{~s}$, while the grain New York-Liverpool berth rate declined 60 percent. Other berth rates were somewhat less affected, as their rate relative to the "Cork for orders" rate indicates. The overall extent of the impact of freight rates is difficult to summarize. 


\section{Appendix}

APPENDIX TABLE 1

EASTBOUND ATLANTIC FREIGHT RATES, 1863-1913

\begin{tabular}{|c|c|c|c|c|}
\hline & & NY-Live & ol Berth & \\
\hline & $\begin{array}{l}\text { Cork for } \\
\text { Orders } \\
\text { (per bushel) }\end{array}$ & $\begin{array}{c}\text { Grain } \\
\text { (per bushel) }\end{array}$ & $\begin{array}{c}\text { Flour } \\
\text { (per } 60 \mathrm{lbs} \text {.) }\end{array}$ & $\begin{array}{c}\text { Cunard, } \\
\text { Home } \\
\text { (per } 60 \mathrm{lbs} \text { ) }\end{array}$ \\
\hline 1863 & 10.4 & & & \\
\hline 1864 & 8.6 & & & \\
\hline 1865 & 8.4 & & & \\
\hline 1866 & 8.2 & & & \\
\hline 1867 & 8.6 & & & \\
\hline 1868 & 9.6 & 6.9 & 7.6 & \\
\hline 1869 & 9.3 & 6.7 & 6.6 & \\
\hline 1870 & 9.5 & 5.7 & 6.1 & \\
\hline 1871 & 10.2 & 8.4 & 8.0 & \\
\hline 1872 & 10.3 & 7.8 & 7.3 & \\
\hline 1873 & 12.8 & 10.5 & 11.5 & \\
\hline 1874 & 9.8 & 8.8 & 7.6 & \\
\hline 1875 & 9.8 & 8.5 & 8.0 & \\
\hline 1876 & 9.1 & 7.9 & & \\
\hline 1877 & 8.9 & & & \\
\hline 1878 & 8.4 & 7.6 & 9.1 & \\
\hline 1879 & 8.1 & 6.2 & 7.8 & \\
\hline 1880 & 7.4 & 5.8 & 7.6 & \\
\hline 1881 & 6.7 & 4.8 & 5.5 & 6.0 \\
\hline 1882 & 7.1 & 4.1 & 5.5 & 6.1 \\
\hline 1883 & 7.3 & 3.6 & 4.2 & 5.8 \\
\hline 1884 & 4.8 & 3.3 & 2.6 & 6.5 \\
\hline 1885 & 5.7 & 2.6 & 3.1 & 5.6 \\
\hline 1886 & 5.1 & 3.4 & 3.4 & 6.4 \\
\hline 1887 & 4.5 & 2.5 & 3.0 & 5.8 \\
\hline 1888 & 5.4 & 2.6 & 3.1 & 6.9 \\
\hline 1889 & 6.8 & 3.9 & 4.4 & 9.8 \\
\hline 1890 & 5.1 & 2.4 & 3.2 & 10.8 \\
\hline 1891 & 5.3 & 3.1 & 3.6 & 12.7 \\
\hline 1892 & 4.7 & 2.6 & 3.3 & 9.8 \\
\hline 1893 & 4.2 & 2.4 & 3.0 & 8.2 \\
\hline 1894 & 4.3 & 1.9 & 2.5 & 8.5 \\
\hline 1895 & 4.3 & 2.2 & 2.5 & 5.5 \\
\hline 1896 & 5.0 & 2.9 & 3.4 & 6.8 \\
\hline 1897 & 4.9 & 3.1 & 3.6 & 6.5 \\
\hline 1898 & 5.4 & 3.4 & 4.4 & 7.3 \\
\hline 1899 & 4.8 & 2.4 & 3.3 & 6.0 \\
\hline 1900 & 5.8 & 3.2 & 4.0 & 6.3 \\
\hline 1901 & 3.7 & 1.2 & 1.9 & 4.1 \\
\hline 1902 & 3.2 & 1.5 & 2.4 & 5.0 \\
\hline 1903 & 3.4 & 1.5 & 2.4 & 6.0 \\
\hline 1904 & 3.5 & 1.1 & 2.0 & 6.4 \\
\hline 1905 & 4.0 & 1.7 & 2.5 & 5.0 \\
\hline 1906 & 3.8 & 1.5 & 2.7 & 4.6 \\
\hline
\end{tabular}




\begin{tabular}{lcccc}
\multicolumn{5}{c}{ APPENDIX TABLE 1 - continued } \\
\hline 1907 & 3.8 & 1.8 & 2.5 & 4.1 \\
1908 & 3.5 & 1.6 & 2.3 & 4.5 \\
1909 & & 1.6 & 2.1 & 4.5 \\
1910 & & 1.5 & 2.4 & 5.3 \\
1911 & & 3.0 & 2.7 & 4.5 \\
1912 & & 3.6 & 4.8 & 5.9 \\
1913 & & 2.8 & 4.7 &
\end{tabular}

Source: "Cork for orders" and Berth rates: 1876-1883; 1888-1913: Annual Statistical Report, New York Produce Exchange. For 1874/5, 1884-1887: average of quote for first issue each quarter, New York Shipping and Commercial List or New York Prices Current. For 1863-1875: average of monthly press quotes from Douglass North's worksheets. Cunard rates: Revenue earned on eastbound voyages divided by tons of freight carried. Cunard Voyage Accounts, University of Liverpool Library.

\section{REFERENCES}

Aduddell, Robert M., and Louis P. Cain. "Location and Collusion in the Meat Packing Industry." In Business Enterprise and Economic Change: Essays in Honor of Harold F. Williamson, edited by Louis P. Cain and Paul J. Uselding, 85-117. Kent, OH: Kent State University Press, 1973.

"Public Policy Toward the "Greatest Trust in the World." Business History Review 55, no. 2 (1981): 217-42.

Andrews, Frank. "Ocean Freights and the Conditions Affecting Them." Washington, DC: GPO, 1907.

Annual Statement of Trade, Parliamentary Papers, various dates.

Annual Statistical Abstract of the United States.

Annual Statistical Report, New York Produce Exchange, 1876-1913.

Bai, Jushan. "Estimation of a Change Point in Multiple Regression Models." The Review of Economics and Statistics 79, no. 4 (1997): 551-63.

Canadian Parliamentary Papers. Reports of Agents of the Canadian Dominion Department of Agriculture in Britain. Various dates.

Carosso, Vincent P. The Morgans: Private International Bankers, 1854-1913. London and Cambridge, MA: Harvard University Press, 1987.

Chandler, Alfred D., Jr. The Visible Hand: The Managerial Revolution in American Business. Cambridge, MA: Harvard University Press, 1977.

Cunard Line Records, University of Liverpool Library.

Epley, Richard J. "Aging Beef." University of Minnesota Extension Service, Bulletin FS-05968, 1992 [www.extension.umn.edu/distribution/nutrition/ DJ5968.html].

Fairplay, various dates.

Feinstein, Charles H. National Income, Expenditure, and Output of the United Kingdom, 1855-1965. Cambridge: Cambridge University Press, 1972.

Goodwin, Barry K., Thomas J. Grennes, and Lee A. Craig. "Mechanical Refrigeration and the Integration of Perishable Commodity Markets." Explorations in Economic History 39, no. 2 (2002): 154-82.

Hansen, Bruce E. "The New Econometrics of Structural Change: Dating Breaks in U.S. Labor Productivity." Journal of Economic Perspectives 15, no. 4 (2001): $117-28$.

Harley, C. Knick. "Western Settlement and the Price of Wheat." This JourNaL 38, no. 4 (1978): 865-78. 
. "Transportation, the World Wheat Trade, and Kuznets Cycle." Explorations in Economic History 17, no. 3 (1980): 218-50.

. "Coal Exports and British Shipping, 1850-1913." Explorations in Economic History 26, no. 3 (1989): 311-38.

. "North Atlantic Shipping in the Late Nineteenth Century: Freight Rates and the Interrelationship of Cargoes." In Shipping and Trade, 1750-1950: Essays in International Maritimes Economic History, edited by Lewis R. Fischer and Helge W. Nordvik, 147-71. Pontefract, U.K.: Lofthouse Publications, 1990.

. "The World Food Economy and Pre-World War I Argentina." In Britain in the World Economy: Essays in Honour of Alec Ford, edited by S. Broadberry and N. Crafts, 244-68. Cambridge: Cambridge University Press, 1992.

. The Integration of the World Economy, 1850-1914. Cheltenham, U.K.: Elgar Reference Collection, 1996.

Heffer, Jean. Le Port de New York et le Commerce Exterieur Americain, 1860-1900. Doctorat d'Etat, Université de Paris I, 1984.

Hooker, R. H. "The Meat Supply of the United Kingdom." The Journal of the Royal Statistical Society 72, no. 2 (1909): 304-76.

Jasny, N. Competition among Grains. Stanford, CA: Stanford University Press, 1940.

Johnson, Emory R., and Grover G. Huebner. Principals of Ocean Transportation. New York: D. Appleton and Co., 1918.

Malenbaum, Wilfred. The World Wheat Economy, 1885-1939. Cambridge, MA: Harvard University Press, 1953.

Markusen, James R. "The Boundaries of Multinational Enterprises and the Theory of International Trade." The Journal of Economic Perspectives 9, no. 2 (1995): 169 89.

Monthly Summary of Commerce and Finance. Grain Trade of the United States, January 1900.

. Provision Trade of the United States, February 1900.

Navin, Thomas R., and Marian V. Sears. "A Study in Merger: Formation of the International Mercantile Marine Company." The Business History Review 28, no. 4 (1954): 291-328.

New York Prices Current, various dates.

New York Shipping and Commercial List, various dates.

Nimmo, Joseph, Jr. Report on the Internal Commerce of the United States. Washington, DC: GPO, 1885.

O'Rourke, Kevin H., and Jeffrey G. Williamson. Globalization and History: The Evolution of a Nineteenth-Century Atlantic Economy. Cambridge, MA: MIT Press, 1999.

Perren, Richard. The Meat Trade in Britain, 1840-1914. London: Routledge \& Kegan Paul, 1978.

Plimsoll, Samuel. Cattle Ships: Being the Fifth Chapter of Mr. Plimsoll's Second Appeal for Our Seamen. London: Kegan Paul, Trench, Trübner, and Co., 1890.

Statistical Abstract of the United Kingdom

Strand, Norman. Prices of Farm Products in Iowa, 1851-1940. Research Bulletin 303 Agricultural Experiment Station, Iowa State College of Agriculture and Mechanic Arts, Ames, IA, 1942.

The Statistical Year Book of Canada for 1901.

U.K. Parliamentary Papers. Select Committee on Cattle Plague and Import of Cattle. 1877 IX. 
Departmental Committee on the Transatlantic Cattle Trade. 1890/1 LXXVIII (C. 6350).

. Departmental Committee on Combinations in the Meat Trade. 1909 XV $(\mathrm{Cd}$ 4661).

. Departmental Committee on Shipping and Shipbuilding. 1918 XIII (Cd. 9092).

Reports of British Consuls in Boston, various dates.

Yeager, Mary. Competition and Regulation: The Development of Oligopoly in the Meat Packing Industry. Greenwich, CT: Jai Press, 1981.

Williamson, Oliver. The Economic Institutions of Capitalism: Firms, Markets, and Relational Contracting. New York: Free Press; London: Collier Macmillan, 1985. 